\title{
FORMULATION AND EVALUATION OF MOUTH DISSOLVING TABLET OF AMLODIPINE BESYLATE
}

\author{
MEGHAWATI R. BADWAR ${ }^{1 *}$, SANDHYA L. BORSE ${ }^{1}$, MANISH S. JUNAGADE ${ }^{2}$, ANIL G. JADHAV ${ }^{3}$
}

${ }^{1}$ Department of Quality Assurance, Sandip Institute of Pharmaceutical Sciences, Mahiravani, Nashik, ${ }^{2}$ Department of Pharmaceutical Chemistry, MGV's SPH College of Pharmacy, Malegaon Camp, Malegaon, ${ }^{3}$ Department of Pharmacognosy, Sandip Institute of Pharmaceutical Sciences, Mahiravani, Nashik

Email: meghabadwar1207@gmail.com

Received: 11 Dec 2018, Revised and Accepted: 26 Apr 2019

\section{ABSTRACT}

Objective: The main objective of this research work was to formulate and evaluate the mouth dissolving tablet of amlodipine besylate for the treatment of hypertension and coronary artery disease.

Methods: In this study, mouth dissolving tablet were prepared by direct compression method by using croscarmellose sodium and sodium starch glycolate as superdisintegrants. The designed tablets were subjected to various assessment parameters like friability test, hardness test, disintegration test, wetting time, in vitro drug release and drug content.

Results: All the prepared formulations were subjected to various assessment parameters, and the findings obtain within the prescribed limit. The calibration curve of pure drug using various solvents like phosphate buffer pH 6.8, methanol was plotted. F1-F9 containing croscarmellose sodium and sodium starch glycolate in various concentration demonstrate the minimum disintegration time. Among all these formulations F9 shows disintegration time up to $22 \pm 1.12$ seconds due to the high concentration of superdisintegrants. In vitro drug release was tested in phosphate buffer pH 6.8 at a time interval of $0,1,2,3,4,5$ min. The F9 shows drug release $100.22 \pm 1.08 \%$. Accelerated stability study of optimized formulation (F9) up to 2 mo showed there was no change in disintegration time and percentage drug release.

Conclusion: The results obtained in the research work clearly showed a promising potential of mouth dissolving tablets containing a specific ratio of croscarmellose sodium and sodium starch glycolate as superdisintegrants for the effective treatment of hypertension and coronary artery disease.

Keywords: Mouth dissolving tablet, Amlodipine besylate, Superdisintegrants, Bioavailability, Calcium channel blocker

(C) 2019 The Authors. Published by Innovare Academic Sciences Pvt Ltd. This is an open-access article under the CC BY license (http://creativecommons.org/licenses/by/4.0/) DOI: http://dx.doi.org/10.22159/ijap.2019v11i4.31288

\section{INTRODUCTION}

Oral route of drug administration has wide acceptance of up to 50$60 \%$ of total dosage forms. Solid dosage forms are popular because of ease of administration, accurate dosage, self-medication, pain avoidance and most importantly the patient compliance. The most popular solid dosage forms are being tablets and capsules, one important drawback of this dosage form for some patients is the difficulty to swallow. Mouth dissolving tablets provide an advantage, particularly for pediatric and geriatric populations who have difficulty in swallowing conventional tablets and capsules. Mouth dissolving of tablet results in quick dissolution and rapid absorption, which provide rapid onset of action. Morever, drug candidates that undergoes pre-gastric absorption when formulated as mouth dissolving tablets may show increased oral bioavailability. It provides good stability, accurate dosing, easy manufacturing. Angina pectoris is chest pain due to ischemia of heart muscle due to obstruction or spasm of the coronary arteries. Amlodipine besylate is a long-acting calcium channel blocker mainly used in the treatment of chronic stable angina vasospastic angina and hypertension. It inhibits the transmembrane influx of calcium ion into vascular smooth muscle and cardiac muscle. Peak plasma concentrations are reached 6-12 h. It has an oral bioavailability of $64-90 \%$ and half-life of about 30-50 h. Amlodipine besylate is a slightly soluble drug the rate of absorption is controlled by the rate of dissolution. The rate of dissolution can be increased by the use of super disintegrants. Mouth dissolving tablets are designed to be placed in mouth allowed to dissolve in the saliva and then swallowed without the aid of water. The objective of the present study was to deliver the drug at a faster rate and to provide immediate onset of action in a shorter period of time with improved bioavailability. The basic approach in the development of oral disintegrating tablets is the use of superdisintegrants like croscarmellose sodium, sodium starch glycolate [1-10].

\section{MATERIALS AND METHODS}

\section{Materials}

Amlodipine besylate procured from Blue cross Pvt. Ltd., Nashik. All the other reagents used were of analytical grade.

\section{Methods}

\section{Determination of $\lambda$ max of amlodipine besylate}

The UV spectrum of amlodipine besylate was obtained by using a UV-visible spectrometer (UV-2450, Shimadzu). Accurately weigh 10 $\mathrm{mg}$ of the drug was added to $100 \mathrm{ml}$ of volumetric flask. Volume was made up to $100 \mathrm{ml}$ with water $(100 \mu \mathrm{g} / \mathrm{ml})$. This solution was used as a stock solution. From this solution $(100 \mu \mathrm{g} / \mathrm{ml})$ suitable working solutions of different concentrations of $10,20,30,140$, and $50 \mu \mathrm{g} / \mathrm{ml}$ were prepared. The resultant solution was scanned from 400 to 200 $\mathrm{nm}$, and the spectrum was recorded to obtain the value of the maximum wavelength in the respective solvents. The absorbance of each standard solution was determined spectrophotometrically. Using absorbance concentration data, Beer-Lambert's plot was constructed [11].

\section{Drug excipients compatibility study Infrared spectrum}

The infrared (IR) spectrum of amlodipine besylate was recorded with potassium bromide $(\mathrm{KBr})$ discover the wave number of 4000 to $400 \mathrm{~cm}^{-1}$ by using fourier transform infrared spectrophotometer (FTIR) [12].

\section{Formulation of mouth dissolving tablets}

Direct compression method was followed to manufacture tablets for all batches. Amlodipine besylate, sodium starch glycolate, croscarmellose sodium, d-Mannitol, microcrystalline cellulose, magnesium stearate, saccharine sodium, were passed through \#690 
sieves. Weighed amounts of the drug as well as all other ingredients were transferred to mortar and blended for 15 min with the help of pestle. The accurately weighed quantity for one tablet was poured in die cavity. Tablet thickness and hardness were adjusted with the help of thickness adjustment screw and compression pressure adjustment knob respectively. Powder filled in die cavity was subjected to compression using 10-station rotary press using round shaped concave punches measuring $8 \mathrm{~mm}$ diameter. Collected tablets were de-dusted and subjected to further evaluation parametes [13]

\section{Formulation optimization}

The $3^{2}$ full factorial design was adopted for formulation purpose. The amount of superdisintegrants, sodium starch glycolate $\left(X_{1}\right)$ and croscarmellose sodium $\left(\mathrm{X}_{2}\right)$ were taken as independent variables. The factors were studied at tree levels $(-1,0,+1)$ indicating low, medium and high, respectively. The statistical optimization procedure was performed with the help of optimization software design expert 8.0.4 (Stat-Ease Inc. MN, USA). The software performs an analysis of variance and statistical optimization.

Table 1: Independent variables

\begin{tabular}{lllll}
\hline Factor level & Coded form & \multicolumn{2}{l}{ Actual value (mg) } & \multicolumn{2}{l}{ Predicted value (mg) } & $\mathbf{X}_{\mathbf{1}}$ \\
\cline { 2 - 5 } & & $\mathbf{X}_{\mathbf{1}}$ & $\mathbf{X}_{\mathbf{2}}$ & 1 \\
\hline Low & -1 & 2 & 1 & 0.5 \\
Medium & 0 & 5 & 3 & 2.5 \\
High & +1 & 8 & 5 & 4 \\
\hline
\end{tabular}

Table 2: Composition of mouth dissolving tablet of amlodipine besylate

\begin{tabular}{|c|c|c|c|c|c|c|c|c|c|}
\hline Ingredients (mg/tablets) & F1 & F2 & F3 & F4 & F5 & F6 & F7 & F8 & F9 \\
\hline amlodipine besylate & 10 & 10 & 10 & 10 & 10 & 10 & 10 & 10 & 10 \\
\hline Croscarmellose sodium & 1 & 3 & 5 & 1 & 3 & 5 & 1 & 3 & 5 \\
\hline sodium starch glycolate & 2 & 2 & 2 & 5 & 5 & 5 & 8 & 8 & 8 \\
\hline d-mannitol & 40 & 40 & 40 & 40 & 40 & 40 & 40 & 40 & 40 \\
\hline microcrystalline cellulose & 93 & 91 & 89 & 90 & 88 & 86 & 87 & 85 & 83 \\
\hline saccharin sodium & 1 & 1 & 1 & 1 & 1 & 1 & 1 & 1 & 1 \\
\hline magnesium stearate & 3 & 3 & 3 & 3 & 3 & 3 & 3 & 3 & 3 \\
\hline total & 150 & 150 & 150 & 150 & 150 & 150 & 150 & 150 & 150 \\
\hline
\end{tabular}

\section{Evaluation}

\section{Precompression parameters}

\section{Angle of repose $(\theta)$}

Angle of repose is defined as the maximum angle possible between the surface of a pile of the powder and horizontal plane. The frictional force in loose powder or granules can be measured by the angle of repose [14].

$$
\tan \theta=\frac{\mathrm{h}}{\mathrm{r}}
$$

Where $\theta=$ angle of repose,

$\mathrm{h}=$ height of the pile,

$r=$ radius of the pile base

\section{Bulk density}

The bulk density of a powder is dependent on particle packing and changes as the powder consolidate. Apparent bulk density was determined by pouring the bulk powder into a graduated cylinder via a large funnel and measuring the volume and weight. Bulk density can be calculated by the following formula $[14,27]$.

$$
\text { Bulk density }=\frac{\text { weight of powder }}{\text { Bulk volume }}
$$

\section{Tapped density}

Tapped density is the bulk density of a powder which has been compacted by tapping or vibration. Tapped density was determined by placing a graduated cylinder containing a known mass of powder on a mechanical tapping apparatus, which is operated for a fixed number of taps (100) or until the powder bed volume has reached a minimum. The tapped density was computed by taking the weight of the drug in the cylinder and final volume [11,28].

$$
\text { Tapped density }=\frac{\text { weight of powder }}{\text { tapped volume }}
$$

\section{Hausner's ratio}

Hausner's ratio is an indirect index of ease of powder flow. It is calculated by the following formula [14]

$$
\text { Hausner's ratio }=\frac{\text { tapped density of powder }}{\text { bulk density of powder }}
$$

\section{Compressibility Index (Carr's Index)}

Another indirect method of measuring powder flow from bulk densities was developed by Carr's. The percentage compressibility of a powder is a direct measure of the potential powder arch or bridge strength and stability. It is calculated according to the following equation [14].

$$
\text { Carr's index }=\frac{\text { (tapped density }- \text { bulk density) }}{\text { tapped density }} \times 100
$$

\section{Weight variation test}

Twenty tablets were selected randomly from each batch and weighed individually in electronic balance (shimadzu). The Indian pharmacopeia allows a little variation in the weight of a tablet. Average weight was calculated, and the standard deviation was computed. Average of 20 readings is taken [14].

\section{Uniformity of thickness}

The thickness of individual tablet may be measured with a digital vernier caliper, which permits accurate measurements and provides information on the variation between tablets. Averages of triplicate readings were taken [14].

\section{Hardness test}

The strength of the tablet is expressed as tensile strength $\left(\mathrm{Kg} / \mathrm{cm}^{2}\right)$. The tablet crushing load, which is the force required to break a tablet into pieces by compression. It was measured using a tablet hardness tester (Monsanto hardness tester). Three tablets from each formulation batch were tested randomly and the average readings were noted $[15,16]$.

\section{Friability}

Friability of the tablets was determined using roche friabilator. This device consists of a plastic chamber that is set to revolve around 25 RPM for 4 min dropping the tablets at a distance of 6 inches with each revolution. Pre-weighed a sample of 20 tablets was placed in the friabilator and was subjected to 100 revolutions. Tablets were dusted using a soft muslin cloth and reweighed. The friability (F \%) was then calculated by $[15,16]$. 
$\%$ Friability $=\frac{\text { (original weight }- \text { weight after } 100 \text { revoluations) }}{\text { original weight }} \times 100$

\section{Drug content}

Twenty tablets from each batch were weighed accurately and powdered. Weight the quantity of the powder equivalent to $100 \mathrm{mg}$ of amlodipine besylate, and was shaken with $100 \mathrm{ml}$ of distilled water in $100 \mathrm{ml}$ volumetric flask. From this $10 \mathrm{ml}$ was pipette out and diluted upto $100 \mathrm{ml}$ with distilled water. From this solution again $10 \mathrm{ml}$ pipette out and diluted up to $100 \mathrm{ml}$ in $100 \mathrm{ml}$ volumetric flask. Resulting solution was filtered and absorbance was checked at $239 \mathrm{~nm}$ and content of amlodipine besylate was calculated using distilled water as a blank [17].

\section{Wetting time}

A piece of tissue paper $(12 \mathrm{~cm} \times 10.75 \mathrm{~cm})$ folded twice was placed in a petri dish (internal diameter $=9 \mathrm{~cm}$ ) containing $9 \mathrm{ml}$ of buffer solution, which had the following to the petri dish. A tablet was carefully placed on the surface of tissue paper. The time required for water to reach the upper surface of the tablets was noted as the wetting time. Six tablets from each formulation batch were tested randomly and the average reading noted [18].

\section{Water absorption ratio}

A petri dish with an inner diameter of $6.5 \mathrm{~cm}$ and having $6 \mathrm{ml}$ water in it was used for this test. A tissue paper folded twice was put in the petri dish. A pre-weighed tablet was positioned on it, after complete wetting the tablet was re-weighed [19].

$$
\mathrm{R}=\frac{\mathrm{Wa}}{\mathrm{Wb}} \times 100
$$

$\mathrm{R}=$ water absorption ratio

$\mathrm{Wa}=$ weight of tablet after wetting

$\mathrm{Wb}=$ weight of the tablet before wetting

\section{In vitro disintegration time}

Disintegration time for mouth dissolving tablets was determined using USP disintegration apparatus with phosphate buffer of $\mathrm{pH}$ 6.8. The volume of the medium was $900 \mathrm{ml}$ and the temperature was $37^{\circ} \mathrm{C} \pm 2$ ${ }^{\circ} \mathrm{C}$. The time in seconds taken for the complete disintegration of the tablet with no palatable mass remaining on the mesh was measured. To comply the test, all tablets should disintegrate within 3 min [18]

\section{In vitro drug release studies}

To study the drug release from the tablet, the USP type II (paddle) apparatus was employed. In this method, $900 \mathrm{ml}$ of phosphate buffer
$\mathrm{pH} 6.8$ was used as the dissolution media and the paddle was rotated at a constant speed of $500 \mathrm{rpm}$. The temperature of the medium was maintained at $37{ }^{\circ} \mathrm{C} \pm 0.5{ }^{\circ} \mathrm{C}$. Sample of $5 \mathrm{ml}$ was removed at an interval of one minute for $7 \mathrm{~min}$. The sample were filtered and the concentration in each sample was determined by UV spectrophotometer and reported as an average of three determinations $[20-24,26]$.

\section{Stability study}

Stability study was conducted as per ICH guidelines $40{ }^{\circ} \mathrm{C} \pm 2{ }^{\circ} \mathrm{C}$, $75 \% \pm 2 \% \mathrm{RH}$ to test the chemical and physical stability of fast dissolving tablets for the period of 2 mo [25].

\section{RESULTS AND DISCUSSION}

\section{Determination of $\lambda$ max of amlodipine besylate}

$\lambda$ max of amlodipine besylate was determined in methanol. The calibration curve of amlodipine besylate shown linearity as per Beers Lambert's law at $239 \mathrm{~nm}$ represented in fig. 1.

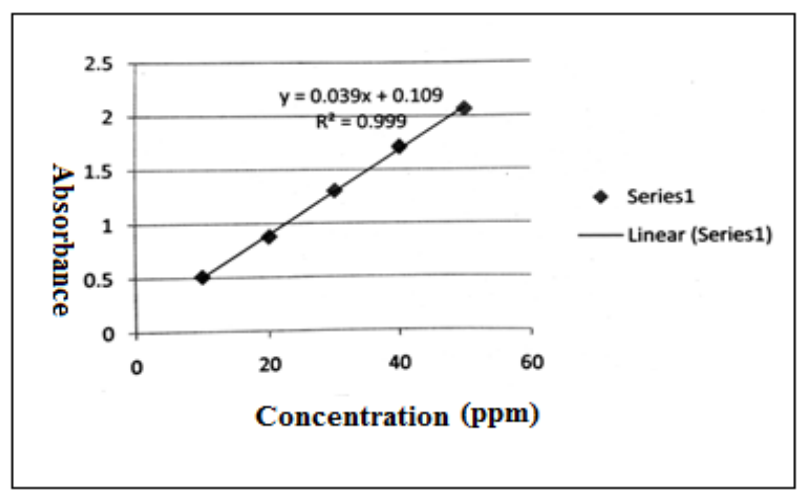

Fig. 1: Calibration curve of amlodipine besylate in methanol

\section{Drug excipients compatibility study IR spectrometer study}

The IR spectra of amlodipine besylate, polymers, and physical mixture are shown in fig. The IR absorption bands observed in the IR spectrum of drug and polymers resembles with that of found in physical mixture proves the compatibility of the drug with polymers. The fig. 3 shows absorption spectrum of drug and croscarmellose sodium and fig. 4 shows an absorption spectrum of drug and sodium starch glycolate [28].






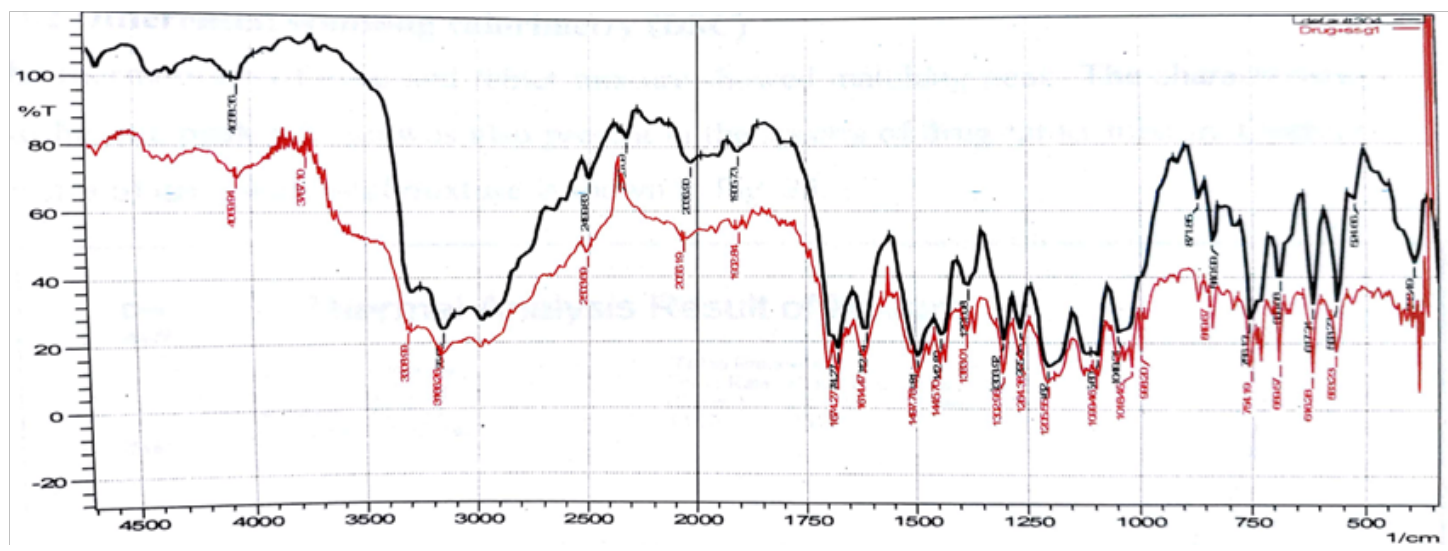

Fig. 2: FTIR of amlodipine besylate

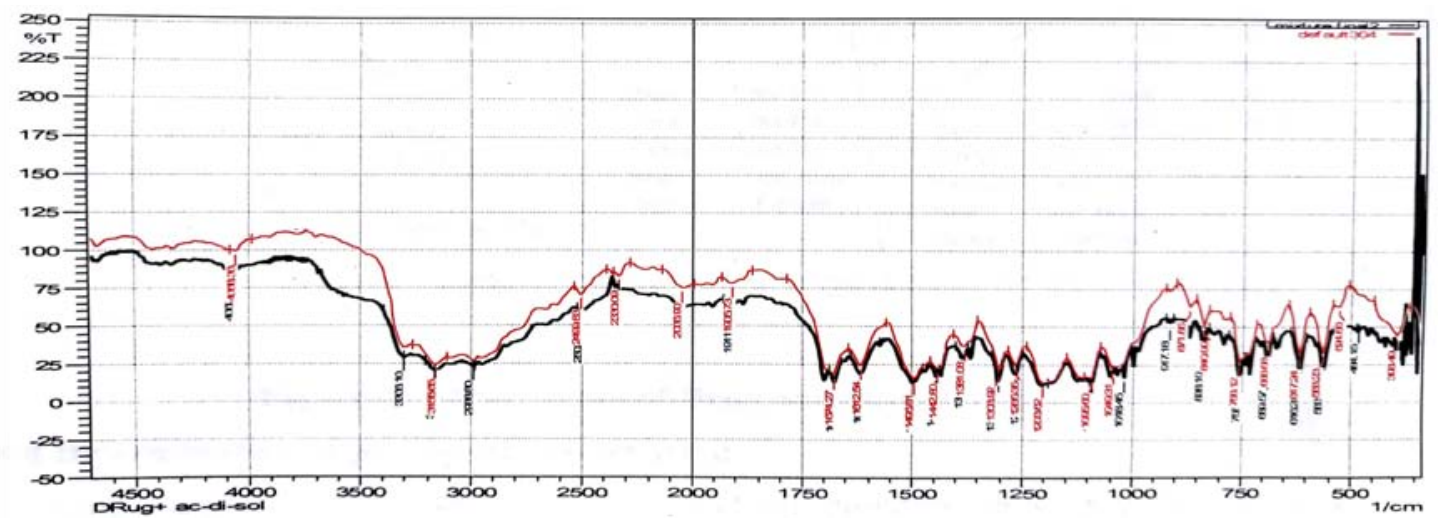

Fig. 3: FTIR spectra of drug and drug+croscarmelose sodium

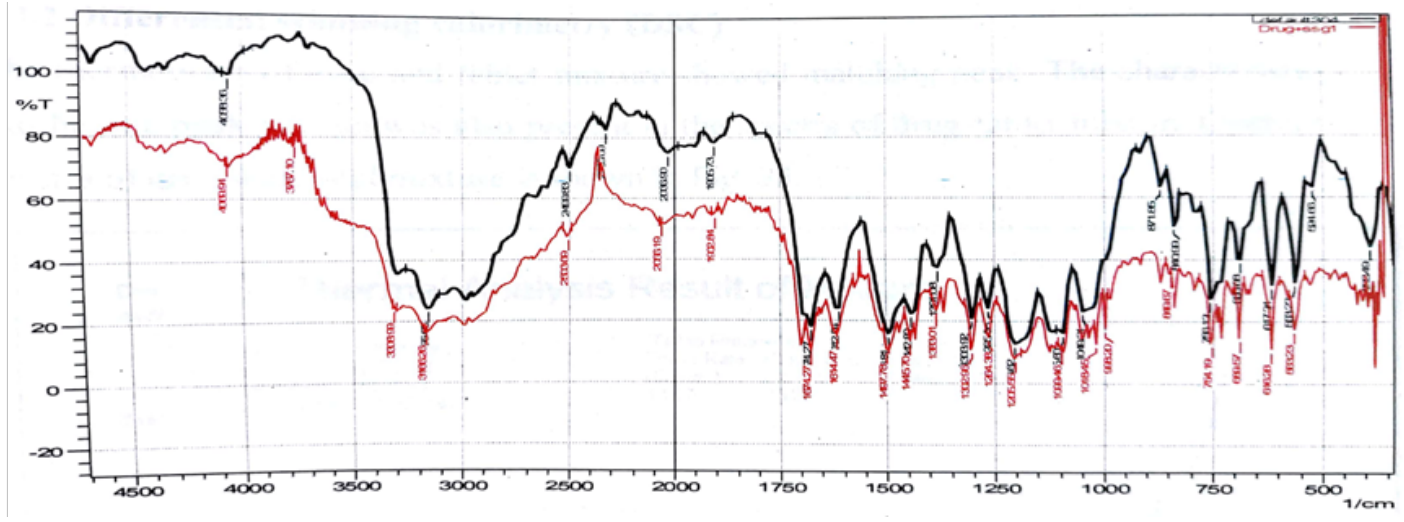

Fig. 4: FTIR spectra of drug and drug+sodiumstarch glycolate

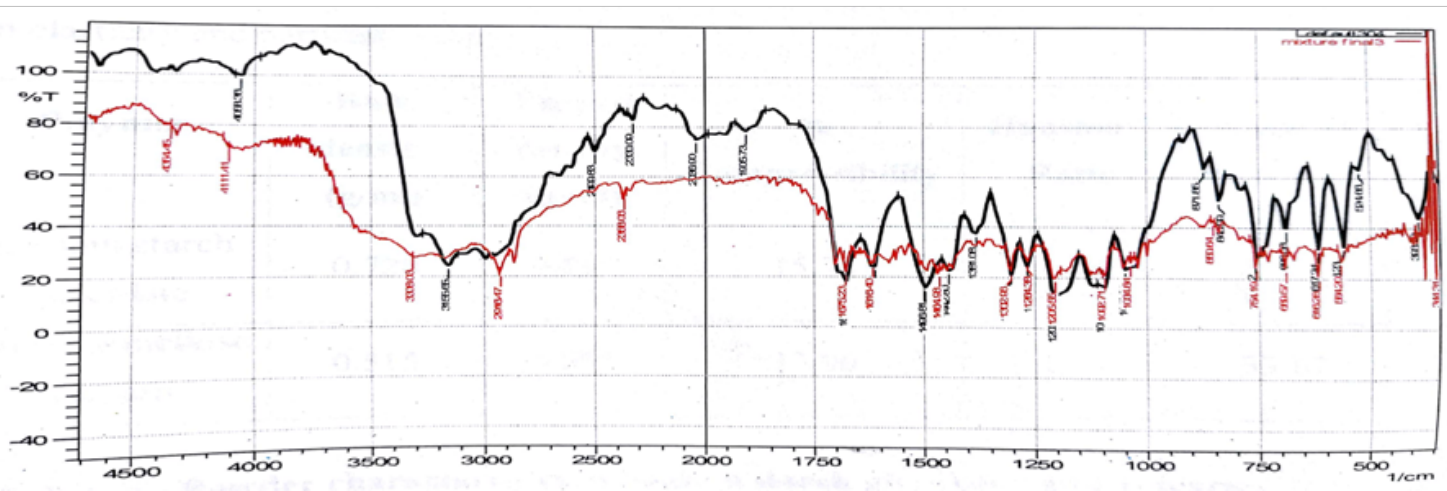

Fig. 5: FTIR spectra of drug and drug+mixture 


\section{Differential scanning colorimetry (DSC)}

Thermal analysis of drugs carried out using DSC. The DSC curve of amlodipine besylate profiles a sharp exothermic peak at $106.53^{\circ} \mathrm{C}$ corrosponding to it's melting, and indicating it's crystalline nature and purity of the sample. The DSC of thermogram is shown in fig. 6. [28].

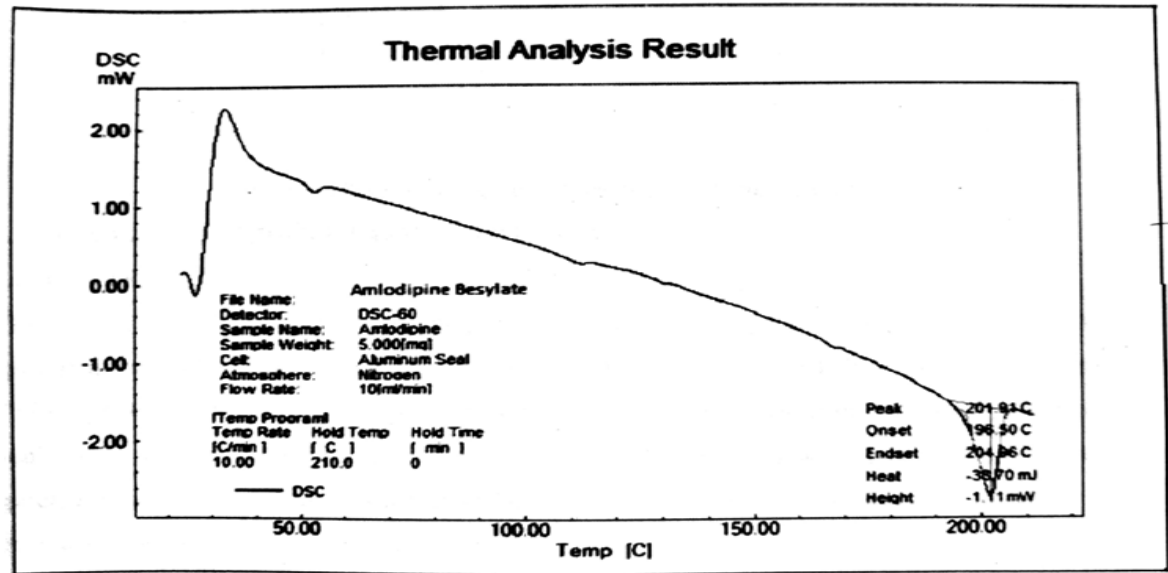

Fig. 6: DSC of amlodipine besylate

The thermogram of drug and tablet mixture showed matching peaks. The characteristic exothermic peak of the drug was also present in the spectra of the drug-tablet mixture. Overlay spectra of drug with the total mixture is shown in fig. 7 .



Fig. 7: DSC of drug+mixture

\section{Precompression evaluation parameters of powder}

\section{Angle of repose}

The angle of repose is an inactive parameter of powder flowability from the hopper to die cavity. An angle of repose between $25^{\circ}$ to $30^{\circ}$ indicates excellent flowability of the powder bed. In this work, the angle of repose was found to be varying between $25.40^{\circ}-29.76^{\circ}$ when glidants were incorporated. These studies indicated that the powder beds of all formulations are easily flow able. All the precompression parameters were found to be within the acceptable limit.

\section{Bulk density}

Bulk density was found in the range of $0.273 \pm 0.0030$ to $0.378 \pm 0.0055 \mathrm{~g} / \mathrm{ml}$.

Table 3: Precompression parameters for fast dissolving tablets of F1 to F9

\begin{tabular}{llllc}
\hline Formulation code & $\begin{array}{l}{ }^{*} \text { Angle of repose } \\
\left({ }^{\circ}\right)\end{array}$ & $\begin{array}{l}{ }^{*} \text { Bulk density } \\
(\mathbf{g} / \mathbf{m l})\end{array}$ & ${ }^{*}$ Tapped density (g/ml) & Compressibility index (\%) \\
\hline F1 & $26.91 \pm 0.021$ & $0.378 \pm 0.0055$ & $0.440 \pm 0.0061$ & $14.12 \pm 2.26$ \\
F2 & $28.02 \pm 0.017$ & $0.353 \pm 0.0028$ & $0.400 \pm 0.0050$ & $11.17 \pm 0.532$ \\
F3 & $27.19 \pm 0.031$ & $0.325 \pm 0.0087$ & $0.393 \pm 0.0057$ & $17.16 \pm 3.38$ \\
F4 & $25.99 \pm 0.075$ & $0.373 \pm 0.0065$ & $0.393 \pm 0.0073$ & $12.25 \pm 2.97$ \\
F5 & $29.76 \pm 0.023$ & $0.329 \pm 0.0028$ & $0.425 \pm 0.006$ & $13.45 \pm 2.05$ \\
F6 & $29.20 \pm 0.051$ & $0.314 \pm 0.002$ & $0.381 \pm 0.0096$ & $8.40 \pm 2.257$ \\
F7 & $25.40 \pm 0.040$ & $0.296 \pm 0.0037$ & $0.343 \pm 0.0070$ & $7.56 \pm 1.100$ \\
F8 & $26.90 \pm 0.025$ & $0.273 \pm 0.0030$ & $0.304 \pm 0.0063$ & 1.206 \\
F9 & $26.75 \pm 0.020$ & $0.295 \pm 0.0015$ & $0.322 \pm 0.0061$ & $1.03 \pm 2.875$ \\
\hline
\end{tabular}

*All the values are expressed as mean \pm SD, where $n=3$, SD: Standard deviation 


\section{Tapped density}

Tapped density was found to be in the range of $0.304 \pm 0.0063$ to $0.440 \pm 0.0061 \mathrm{~g} / \mathrm{ml}$.

\section{Percentage compressibility index}

Compressibility index was found to be in the range of $7.56 \%$ to $17.16 \%$. All formulations showed good flow properties which are given in table 3 .

\section{Hausner's ratio}

Hausner's ratio was found to be in the range of 1.073 to 1.206 [24].

Post-compression evaluation of fast dissolving tablets of amlodipine besylate

\section{Thickness}

The thickness of the tablets was found to be uniform, between $2.21 \pm 0.005 \mathrm{~mm}$ to $2.29 \pm 0.005 \mathrm{~mm}$ for (F1 to F9).

\section{Hardness}

The hardness of the tablets varied between $2.89 \pm 0.036 \mathrm{Kg} / \mathrm{cm}^{2}$ to $3.78 \pm 0.047 \mathrm{Kg} / \mathrm{cm}^{2}$ indicating good binding and satisfactory strength of tablets to withstand stresses during transportation and also may offer good dissolution property.

\section{$\%$ Friability}

The $\%$ friability was found in the range of $0.44 \pm 0.05 \%$ to $0.88 \pm 0.06 \%$ which passes standard.

\section{Weight variation}

The weight of the formulated tablets of amlodipine besylate (F1 to F9) was found to be uniform with low standard deviation values from $148.96 \pm 1.35$ to $150.56 \pm 1.44 \mathrm{mg}$. The prepared formulations comply with the weight variation test as per IP. The results are given in table 4.

\section{Water absorption ratio}

The water absorption ratio ranged from $95.33 \pm 0.67$ to $100.89 \pm 1.01$. All the formulations pass the test as per IP standards [24]

\section{Wetting time}

It is the time required for complete wetting of tablet. The wetting time was found in the range of $15 \pm 0.56$ to $31 \pm 0.89 \mathrm{sec}$.

\section{Disintegration time}

It is the time required for complete disintegration of the tablet. The disintegration time was found in the range of $22 \pm 1.12$ to $35 \pm 1.84$ sec.

\section{Drug content}

Drug content found in the fast dissolving tablets resembling that of literature value. Range of drug content is $95.16 \%-101.28 \%$. Therefore uniformity of content was maintained in all formulations. Drug content of all formulations is listed in table 4. [24].

Table 4: Post compression parameters for mouth dissolving tablets of F1 to F9

\begin{tabular}{|c|c|c|c|c|c|}
\hline $\begin{array}{l}\text { Formulation } \\
\text { code }\end{array}$ & $\begin{array}{l}\text { Thickness } \\
(\mathrm{mm})(\text { mean } \pm S D)\end{array}$ & $\begin{array}{l}\text { Hardness* } \\
\left(\mathrm{Kg} / \mathrm{cm}^{2}\right)(\text { mean } \pm S D)\end{array}$ & $\begin{array}{l}\text { Friability \% } \\
\text { (mean } \pm \text { SD) }\end{array}$ & $\begin{array}{l}\text { Average weight } \\
\text { Mg (mean } \pm S D)\end{array}$ & Water absorption ratio \\
\hline F1 & $2.21 \pm 0.005$ & $3.46 \pm 0.028$ & $0.62 \pm 0.05$ & $149.1 \pm 1.04$ & $98.21 \pm 1.389$ \\
\hline $\mathrm{F} 2$ & $2.25 \pm 0.01$ & $3.14 \pm 0.128$ & $0.58 \pm 0.03$ & $149.3 \pm 1.84$ & $100.89 \pm 1.01$ \\
\hline F3 & $2.26 \pm 0.032$ & $3.78 \pm 0.047$ & $0.58 \pm 0.08$ & $148.96 \pm 1.35$ & $97.99 \pm 0.665$ \\
\hline $\mathrm{F} 4$ & $2.29 \pm 0.005$ & $3.38 \pm 0.047$ & $0.55 \pm 0.06$ & $150.56 \pm 1.44$ & $99.3 \pm 0.10$ \\
\hline F5 & $2.22 \pm 0.015$ & $3.63 \pm 0.015$ & $0.54 \pm 0.08$ & $149.16 \pm 0.93$ & $96.44 \pm 0.38$ \\
\hline F6 & $2.22 \pm 0.015$ & $2.95 \pm 0.046$ & $0.45 \pm 0.06$ & $149.1 \pm 1.04$ & $97.29 \pm 0.28$ \\
\hline F7 & $2.22 \pm 0.01$ & $3.15 \pm 0.132$ & $059 \pm 0.02$ & $149.34 \pm 0.87$ & $99.99 \pm 1.32$ \\
\hline F8 & $2.23 \pm 0.115$ & $2.89 \pm 0.036$ & $0.44 \pm 0.05$ & $150.1 \pm 1.31$ & $95.33 \pm 0.67$ \\
\hline F9 & $2.25 \pm 0.01$ & $3.22 \pm 0.0023$ & $0.88 \pm 0.06$ & $150.19 \pm 1.10$ & $96.6 \pm 0.38$ \\
\hline
\end{tabular}

*All the values are expressed as mean $\pm \mathrm{SD}$, where $\mathrm{n}=20$ and $\# \mathrm{n}=3$

Table 5: Post compression parameters for mouth dissolving tablets of F1 to F9

\begin{tabular}{lll}
\hline Formulation code & Wetting time*(Sec) (mean \pm SD) & $\begin{array}{l}\text { Disintegration time (Sec) } \\
\text { (mean } \pm \text { SD) }\end{array}$ \\
\hline F1 & $20 \pm 0.88$ & $25 \pm 1.76$ \\
F2 & $22 \pm 0.67$ & $28 \pm 1.34$ \\
F3 & $31 \pm 0.89$ & $35 \pm 1.84$ \\
F4 & $21 \pm 0.87$ & $26 \pm 1.36$ \\
F5 & $27 \pm 0.98$ & $32 \pm 1.25$ \\
F6 & $22 \pm 0.32$ & $28 \pm 1.45$ \\
F7 & $28 \pm 0.77$ & $34 \pm 1.69$ \\
F8 & $18 \pm 0.65$ & $24 \pm 1.77$ \\
F9 & $15 \pm 0.56$ & $22 \pm 1.12$ \\
\hline
\end{tabular}

All the values are expressed as mean $\pm S D, S D$ : Standard deviation, where* $n=3$.

$\%$ cumulative drug release of the different formulations is shown in fig. 4. In this formulations as the level of croscarmellose sodium and sodium starch glycolate is increased the drug release will also increases. Release of the drug in vitro, was determined by estimating the dissolution profile, USP 2 paddle apparatus was used and the paddle was allowed to rotate at $50 \mathrm{rpm}$, phosphate buffer ( $\mathrm{pH}$ 6.8) (900 ml) was used as a dissolution medium [28].

\section{$\%$ cumulative drug release}

$\%$ cumulative drug release was found in the range of $90.57 \pm 0.99$ to $99.65 \pm 0.63 \%$. 


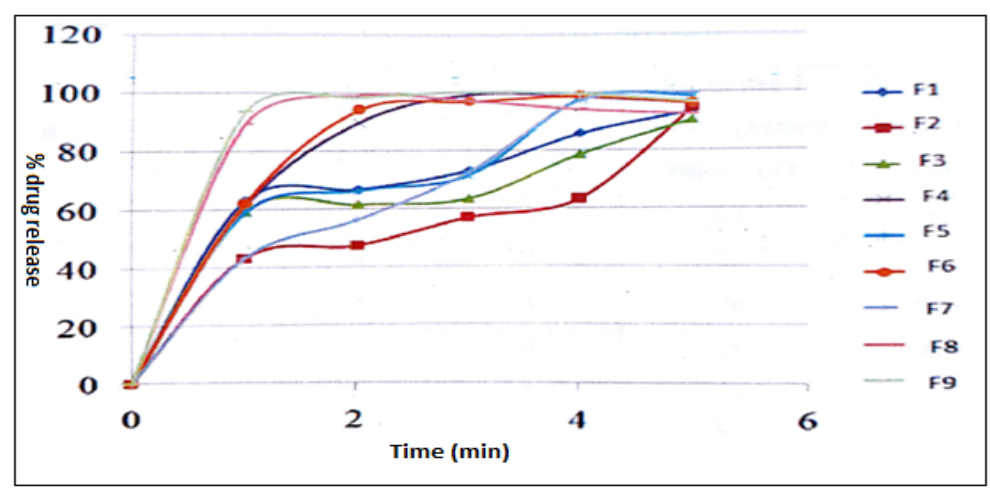

Fig. 8: Graph of \%drug release of mouth dissolving tablet of amlodipine besylate

Table 6: Stability study of the optimized formulation

\begin{tabular}{llll}
\hline S. No. & Observations & $\begin{array}{l}\text { Before stability } \\
*(\mathbf{m e a n} \pm \mathbf{S D})\end{array}$ & Stability testing interval days \\
\hline 1 & & White & 1 mo *(mean \pm SD) \\
2 & Visual Appearance & $22 \pm 1.12$ & White \\
3 & disintegration time $(\mathrm{sec})$ & $99.24 \pm 0.26$ & $22 \pm 1.35$ \\
\hline
\end{tabular}

*All values are mean \pm SD, SD: Standard deviation, where* $n=3$

\section{Stability study}

Results of the stability studies showed that there is no change in the physical parameters of the formulation. Drug content of the formulation was also found to be same as that before stability testing. Stability data is shown in table 6 .

\section{CONCLUSION}

The current studies are aimed at successful development and optimization of the mouth dissolving tablet of amlodipine besylate and to enhance the bioavailability of the drug by avoiding first pass effect. Among the prepared batches of tablets based on performance with respect to friability, hardness, uniformity of drug content, disintegration and in vitro drug release studies, F9 delivers the best results as compared to other formulations. Thus, drug release from the mouth dissolving tablet was increased by using the increased concentration of superdisintegrants, assisting in faster disintegration in the oral cavity. As the drug having fast disintegration may leads to more drug availability for dissolution, resulting in faster absorption and possibly bioavailability leads to the quick onset of action in the systemic circulation.

\section{ACKNOWLEDGMENT}

Authors are thankful to Mr. M. S. Junagade for their valuable guidance. Literature review, experimental work, development, optimization of the formulations and interpretation of results was done by Ms. M. R. Badwar.

\section{AUTHORS CONTRIBUTIONS}

All the author have contributed equally

\section{CONFLICT OF INTERESTS}

Declared none

\section{REFERENCES}

1. Seager H. Drug delivery products and the zydis fast dissolving dosage form. J Pharm Pharmacol 1998;4:375-82.

2. Prajapati BG, Patel B. Formulation, evaluation and optimization of orally disintegrating tablet of piroxicam. Int J Pharma Tech Res 2010;2:1893-9.

3. Patidar A, Mishra P, Main P, Harsoliya MS, Agrawal S. A review on recent advancement in the development of rapid disintegrating tablet. Pharm Sci Pharm 2011;1:7.
4. Sastry SV, Nyshadham JR, Fix JA. Recent technological advances in oral drug delivery. A review. Pharm Sci Technol Today 2000;3:138-45

5. Habib W, Khankari RK, Hontz J. Fast-dissolve drug delivery systems. Crit Rev Ther Drug Carrier Sys 2000;2:61-72.

6. Lindgren S, Janzon L. Dysphagia: prevalence of swallowing complaints and clinical finding. Med Clin North Am 1993;6:3-5.

7. Muhammad AS, Syed FA, Marium FK, Sofia A, Iqbal A Formulations of amlodipine: a review. J Pharm 2016;1-11. http://dx.doi.org/10.1155/2016/8961621

8. Deepthi PR, Satish KK. Formulation and evaluation of amlodipine besylate oral thin films. Int J Pharma Sci Res 2016;7:199-205.

9. Shireen B, Syed AAB, Shazia F. Formulation and in-vitro evaluation of mouth dissolving tablets of amlodipine and rosuvastatin. Int J Curr Pharm Res 2015;7:88-91.

10. Nirav VP, Sachin C, Chintan Aundhia, Seth AK. Formulation and evaluation of amlodipine besylate orally disintegrating tablet. Indo Am J Pharma Res 2011;2:146-52.

11. Vijaya VCS, Vidyavathi M. Preparation and in vitro characterization of bosentan monohydrate mucoadhesive microspheres. Eur J Pharma Med Res 2016;3:340-50.

12. Chatwal GR, Anand SK. Instrumental methods of instrumental methods of chemical analysis. $5^{\text {th }}$ Edition. Himalaya Publishing House; 2009. p. 2.49-2.51.

13. Nirav VP, Sachin C, Chintan Aundhia, Seth AK. Formulation and evaluation of amlodipine besylate orally disintegrating tablet. Indo Am J Pharma Res 2011;2:146-52.

14. Bele $\mathrm{MH}$. Pharmaceutics formulation and processing of conventional dosage form. First Edition. Carrer Publication; 2012. p. 48-55, 128-131.

15. Kalia A, Khurana S, Bedi N. Formulation and evaluation of mouth dissolving tablet of oxcarbazepine. Int J Pharm Pharm Sci 2009;1:12-3.

16. Jain C, Naruka P. Formulation and evaluation of fast dissolving tablet of valsartan. Int J Pharm Pharm Sci 2009;1:219-26.

17. Indian Pharmacopoeia. Government of India Ministry of Health and Family Welfare, Published by The Indian Pharmacopoeal Commission, Ghaziabad; 2014. p. 2964, 1469, 2143, 2151.

18. Sudhir B, Vinay J, Jar RC, Ashish M, Suman J. Formulation and evaluation of fast dissolving tablets of aceclofenac. Int J Drug Delivery 2010;2:93-7.

19. Kuchekar B, Badhan A, Mahajan H. Mouth dissolving tablets of salbutamol sulphate: a novel drug delivery system. Indian Drugs 2004;41:592-8. 
20. Arunachalam A, Lavakumar V, Shankar M. Formulation and in vitro evaluation of levofloxacin oral dispersible tablets. Asian J Res Chem Pharm Sci 2013;1:31-9.

21. Dobetti L. Fast melting tablet: development and technologies. Pharm Tech 2001;2:44-8.

22. Lorenzp Lamosa ML, Cuna M, Vila Jato JL, Torres D. Fast dissolving drug delivery system. J Microencapsul 1997;14:607.

23. Virley P, Zydis YR. A novel fast dissolving dosage form. Manuf Chem 1990;2:36-7.
24. Shinkar DM, Aher PS, Kothwade PD, Maru AD. Formulation and in vitro evaluation of verapamil hydrochloride. Int J Pharm Pharm Sci 2018;10:93-9.

25. Caretensen JT. Guidelines for drug stability: principles and practices. Third Edition. Marcel Dekkar; 2005. p. 252-5.

26. Pratik SD, Sushma V, Puja S. Fast dissolving tablet using solid dispersion technique: a review. Int J Curr Pharm Res 2017;9:1-4.

27. Roy A. Orodispersible tablet: a review. Asian J Pharm Chem Res 2016;2:19-26

28. Jaya S, Amala V. Formulation and in vitro evaluation of ora disintegrating tablets of amlodipine besylate. Int J Appl Pharm 2019;11:49-54 